\title{
Kuga Mine
}

by Yoshinori KUBOTA and Hitoji IWABUCHI

The Kuga mine are located at Negasa, Mikawa Town, Yamaguchi Prefecture, started the operation in 1953, treating the production of 2300 tons tungsten-copper ore per month. Monthly production are approximately 15 tons of scheelite concentrate, 3 tons of scheelite-cassiterite mixed concentrate, 90 tons of copper concentrate.

The geology of the mine is underlain by the Triassic Kuga Group which consists of slates, cherts, sandstones and limestones. The ore bodies are tungsten-copper deposits of a contact-skarn type which is controled by the structure of the anticlinorum and the synclenorum. The mining methods are breast stoping and sublevel stoping. The transportation is track method used battery locomotive. The ventilation and the drainage methods are almost native. The number of underground artisans are 18 and they are all contracted men.

\section{[1-23]藤 ケ 谷 鉱 山}

湯 沢 義 晴 $^{1}$

\section{1. 緒言}

\section{1・1，位置交通 (第 1 図参照)}

山口県岩国市の西方約 $14 \mathrm{~km}$ に位置し，岩国駅から岩徳線で約 30分にて周防高森駅に達し, これより県道沿い北方約 $11 \mathrm{~km}$ の地 点に当所の採鉱場がある。さらに北 $1 \mathrm{~km}$ の所に鉱山事務所と選 鉱場がある。また岩日線根笠駅より南東約 $11 \mathrm{~km}$ 県道沿いに藤ヶ 谷部落を経て鉱山事務所に至る。

\section{$1 \cdot 2$ 気 埃}

鉱山事務所附近は海拔 $540 \mathrm{~m}$ で冬期は気温が零下 $5 \sim 10{ }^{\circ} \mathrm{C}$ に低 下寸る場合もあるが，積雪は少なく，年間を通じて淩ぎ良い環境 にある。

\section{$1 \cdot 3$ 沿 革}

明治 40 年 喜久鉱山と称し稼行されたが，その後幾多の変 遷を経て昭和23年全面的に閉山

昭和26年 6 月 日本鉱業㑣が鉱業権を取得，藤ヶ谷探鉱所とし て，旧坑取明けによる探鉱を開始

昭和30年 6 月 日本鉱業(保河山鉱業所支山として, 月産 $300 \mathrm{t}$

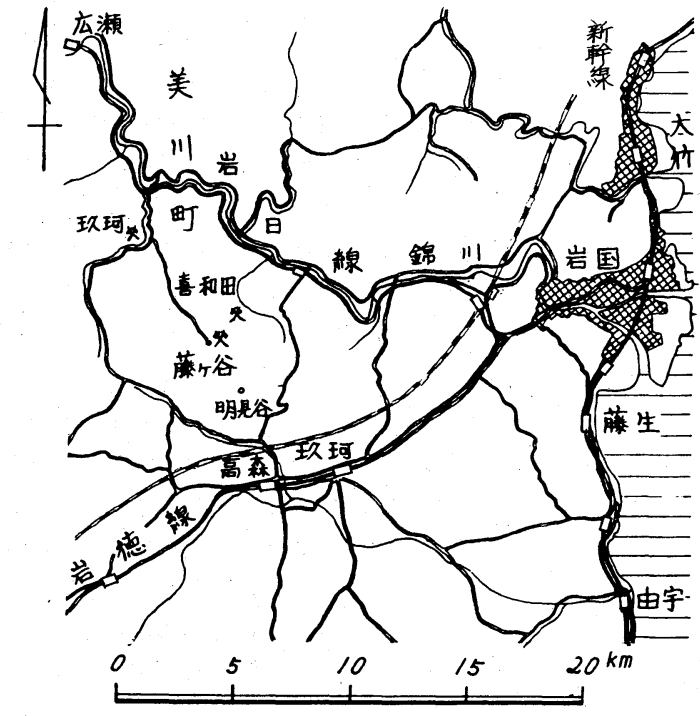

第 1 図 藤ヶ谷鉱山位置図

1. 正会員 藤ヶ谷鉱山株式会社鉱務課長

\begin{tabular}{rr|r|r|r}
\multicolumn{5}{c}{ 第 1 表 従業員 } \\
\hline & & 坑内 & 坑外 & 計 \\
\hline 職 & 員 & 3 & 3 & 6 \\
従業員 & 27 & 15 & 42 \\
\hline \multicolumn{2}{|c|}{ 計 } & 30 & 18 & 48 \\
\hline
\end{tabular}

第 2 表 粗鉱量と出鉱品位

\begin{tabular}{c|c}
\hline \multirow{2}{*}{ 粗鉱量 $(t)$} & 品 位 \\
\cline { 2 - 2 } & $\mathrm{WO}_{3}(\%)$ \\
\hline 1,650 & 0.95 \\
\hline
\end{tabular}

\section{処理の選鉱操業を開始}

昭和38年 3 月 タングステン市沉悪化のため休山

昭和 41 年11月 鐘打鉱業侏鉱業権を日本鉱業侏より譲受ける

昭和 42 年 10 月 選鉱場新設完成, 月産 $1200 \mathrm{t}$ 処理

昭和 43 年 4 月 月産 $1600 \mathrm{t}$ 処理

昭和 57 年 8 月 鐘打釷業森より分離独立，藤ヶ谷鉱山(㑣を設立 昭和57年10月 鐘打鉱業㑣より鉱業権，その他諸施設一切を譲 受け，操業を継続現在に至る

$1 \cdot 4$ 現 状

（1）従業員 （第 1 表参照 )

（2）粗鉱量と出鉱品位 （第 2 表参照 ）

\section{2. 地質鉱床の要約}

\section{$2 \cdot 1$ 地 質}

当山付近の地質は㺵珂郡層に属する粘板岩, チャート, 石灰岩 および砂岩等の堆積岩と, これを貫く, アプライト, 玢岩等の岩 脈よりなる。鉱床付近の粘板岩は, 黒雲母ホルンフエルス化して おり，地層の一般走向は $\mathrm{N} 70^{\circ} \mathrm{W} \sim \mathrm{N} 50^{\circ} \mathrm{E}$, 傾斜 $15^{\circ} \sim 50^{\circ} \mathrm{N}$ 示 すが，EW系の軸をもつた，褟曲を繰返している。また堆積岩の 線方向はN $60^{\circ} \sim 80^{\circ} \mathrm{W}, 20^{\circ} \sim 35^{\circ} \mathrm{NWに}$ 集約される。主な断層は 走向 $\mathrm{N} 20^{\circ} \sim 50^{\circ} \mathrm{E}$ ，傾斜 $30^{\circ} \sim 60^{\circ} \mathrm{NW}$ を示す正断層が多い。

\section{$2 \cdot 2$ 鉱 床}

鉱床は石灰岩または石灰岩質を皮殼状か塊状に交代したものと， 含灰重石石英脈に大別され，交代鉱床は線構造方向に連なり，北 側より郡林, 三つ石鉱床，向銿，五仙峠鉱床群，明見谷鉱床群お よび樅の木鉱床群が並列する。石英脈は一般に走向 $\mathrm{N} 20^{\circ} \sim 50^{\circ} \mathrm{E}$ を示し東へ急傾斜する細脈で五仙峠，明見谷の坑内で多く認めら れる。採掘中の明見谷第 1 鉱体および第 5 鉱体は，走向延長 100 $\mathrm{m}$ ，傾斜延長 $250 \mathrm{~m}$ ，厚さ $30 \mathrm{~m}$ のレンズ石灰岩が不規則皮殼状に

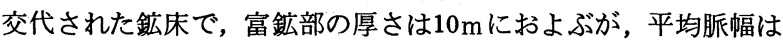




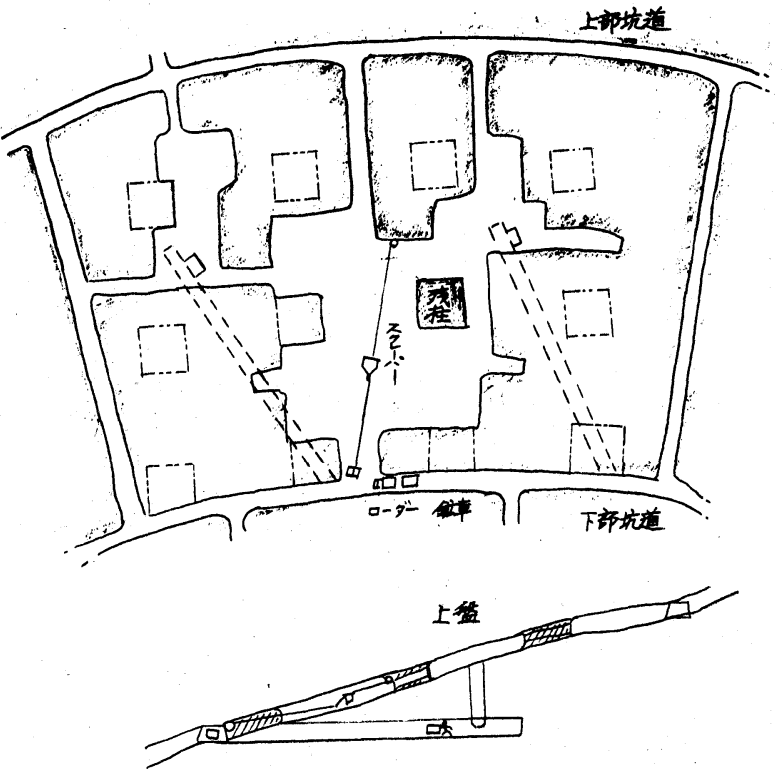

第2図残柱式採掘法

第3表 採掘法別出鉱量および切羽数 (58年度実績)

\begin{tabular}{c|c|c|c}
\hline 採掘法の種類 & 出 鉱 量 & 出鉱比率 & 切 羽 数 \\
\hline 残 柱式採掘 法 & $16,725 \mathrm{t}$ & $81 \%$ & 15 \\
下向充填採掘法 & 2,446 & 12 & 1 \\
探 開 坑 雑 鉱 & 1,502 & 7 & 2 \\
\hline 計 & 20,673 & 100 & 18 \\
\hline
\end{tabular}

第 4 表 探開坑および試錐延長

\begin{tabular}{c|c|c}
\hline 探鉱延長 & 開坑延長 & 試錐延長 \\
\hline $937.9 \mathrm{~m}$ & $187.6 \mathrm{~m}$ & $2437.7 \mathrm{~m}$ \\
\hline
\end{tabular}

第 5 表 過去 10 年間の年間出鉱量，平均品位および能率 (坑内, 全山 ) の推移

\begin{tabular}{c|c|c|c|c}
\hline \multirow{2}{*}{ 年 度 } & \multirow{2}{*}{$\begin{array}{c}\text { 年間出鉱量 } \\
(\mathrm{t})\end{array}$} & 平均品位 & \multicolumn{2}{|c}{ 1 人 1 月当出鉱量 } \\
\cline { 3 - 5 } & & $\mathrm{WO}_{3}$ & $\begin{array}{c}\text { 坑 内 } \\
(\mathrm{t})\end{array}$ & $\begin{array}{c}\text { 全 } \\
(\mathrm{t})\end{array}$ \\
\hline 49 出 & 17,767 & 1.18 & 44.9 & 24.1 \\
50 & 17,824 & 1.06 & 40.1 & 22.5 \\
51 & 19,224 & 0.93 & 48.5 & 28.1 \\
52 & 20,077 & 0.75 & 54.0 & 29.4 \\
53 & 20,166 & 0.84 & 56.0 & 30.6 \\
54 & 19,768 & 0.76 & 54.9 & 30.0 \\
55 & 18,990 & 0.75 & 51.9 & 28.3 \\
56 & 19,391 & 0.87 & 49.7 & 26.5 \\
57 & 19,501 & 0.94 & 47.8 & 28.0 \\
58 & 20,673 & 0.98 & 54.0 & 32.9 \\
計 & 193,381 & & & \\
平均 & 19,338 & 0.90 & 49.9 & 27.8 \\
\hline
\end{tabular}

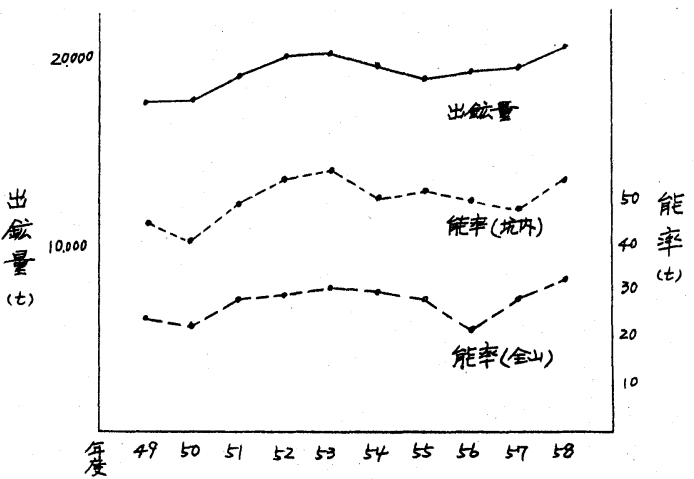

に灰重石, 磁硫鉄鉱, 黄銅鉱, 黄鉄鉱を含有し, 少量の閃亜鉛鉱, 方鉛鉱, 輝水鉛鉱, 錫石が存在する。

3. 採掘法

$3 \cdot 1$ 残柱式採掘法 (第 2 四参照)

鉱石の一部を採掘せず鉱柱として残し， その鉱柱で天盤を支えながら採掘する無支 保の採掘方法である。垂直間隔 $20 \mathrm{~m}$ 毎に行 なわれた環状銿押坑道から石灰岩の上盤と 下盤側へ鉱床の傾斜に沿つて，銿押斜坑を 開さくし，この斜坑を中心に薄い鉱床は, 坑道を追切りするようにしながら採掘し， 鉱柱は規則正しく残すか，あるいは，低品 位部を残すようにする。厚い鉱床の場合は 一般にまず上盤側を薄い場合と同様に追切 採掘し，ついで下部に向つて何段かの階段 分割して, 下向階段状に採掘してゆく。

盤殴はほとんどないといつてよく，母岩， 鉱石ともに硬いが，母岩の亀裂の多い簀所， 鉱床に貫入しているアプライトは節理が発

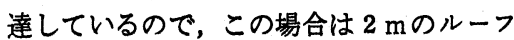
ボルトおよび金網で支保する。鉱床は不規 則不安定で品位のバラッキが著しく，出鉱 品位の平均化が難しい, したがつて画一的 に採掘を進めるわけにもいかず，採掘出鉱 量のわりには切羽数を多くし，交互に稼働 するなどの方策が必要である。切羽運搬は

图下向充填採掘法

約 $1 \mathrm{~m}$ ，品位はWO 3 が $0.6 \%$ \%゙る。

鉱石は柘榴石を主とする灰鉄輝石, 透輝石, 緑泥石, 緑れん石 白雲母, 方解石, 石英と少量の蛍石, 燐灰石よりなるスカルン中
$5 \mathrm{P} \sim 7.5 \mathrm{P}$ エアースラッシャまたは10P電動スラッシャを使用 している。

$3 \cdot 2$ 下向充顷採㨄法 (第 3 図参照) 
第 6 表 58年度 採掘工程, 原単位および直接採掘費, 採鉱費

\begin{tabular}{|c|c|c|c|c|c|c|c|c|c|c|c|c|c|c|c|}
\hline & \multirow{2}{*}{ 出 鉱 量 } & \multirow{2}{*}{\multicolumn{2}{|c|}{\begin{tabular}{|lr|lr|} 
純 & 採 & 掘 & 直 \\
鉱 & 接 \\
& 量 & 採掘工数
\end{tabular}}} & \multicolumn{2}{|c|}{ 原 } & \multicolumn{2}{|c|}{ 単 位 } & \multicolumn{4}{|c|}{ 直接採 掘費 } & \multicolumn{2}{|r|}{ 採 } & \multicolumn{2}{|c|}{ 鉱費 } \\
\hline & & & & 工 数 & 爆 薬 & 坑 木 & 電 力 & 人件費 & 物品費 & 経 費 & 計 & 人件費 & 物品費 & 経 費 & 計 \\
\hline 58 年 & $1,773^{t}$ & $1,574^{t}$ & 285.2 & $\begin{array}{l}I / t \\
0.18\end{array}$ & $\begin{array}{l}\mathrm{kg} / \mathrm{t} \\
0.797\end{array}$ & $\begin{array}{r}\mathrm{m}^{3} / \mathrm{t} \\
0.0034\end{array}$ & $\begin{array}{c}\mathrm{kWh} / \mathrm{t} \\
39.3\end{array}$ & $\begin{array}{r}\text { 円/t } \\
2,237\end{array}$ & $\begin{array}{c}\text { 円/t } \\
430\end{array}$ & $\begin{array}{c}\text { 円 } / \mathrm{t} \\
130\end{array}$ & $\begin{array}{r}\text { 円/t } \\
2,797\end{array}$ & $\begin{array}{l}\text { 円 } / \mathrm{t} \\
4,670\end{array}$ & $\begin{array}{r}\text { 円/t } \\
629\end{array}$ & $\begin{array}{l}\text { 円/t } \\
975\end{array}$ & $\begin{array}{r}\text { 円 } / \mathrm{t} \\
6,274\end{array}$ \\
\hline 5 & 1,685 & 1,535 & 232.5 & 0.15 & 0.643 & 0.0023 & 38.2 & 2,620 & 669 & 120 & 3,409 & 5,117 & 1,051 & 1,000 & 7,168 \\
\hline 6 & 1,914 & 1,844 & 284.6 & 0.15 & 0.824 & 0.0030 & 33.5 & 2,150 & 557 & 107 & 2,814 & 4,021 & 700 & 836 & 5,557 \\
\hline 7 & 1,654 & 1,587 & 294.4 & 0.19 & 1.099 & 0.0035 & 38.6 & 2,567 & 855 & 92 & 3,514 & 4,811 & 951 & 977 & 6,739 \\
\hline 8 & 1,789 & 1,781 & 288.4 & 0.16 & 0.946 & 0.0035 & 31.3 & 2,377 & 681 & 109 & 3,167 & 4,189 & 865 & 846 & 5,900 \\
\hline 9 & 1,698 & 1,455 & 291.2 & 0.20 & 1. 141 & 0.0064 & 39.7 & 2,749 & 1,158 & 129 & 4,036 & 5,218 & 1,536 & 1,091 & 7,845 \\
\hline 58/上小計 & 10,513 & 9,776 & 1676.3 & 0.17 & 0.905 & 0.0036 & 36.5 & 2,436 & 714 & 114 & 3,264 & 4,635 & 938 & 947 & 6,520 \\
\hline 10 & 1,640 & 1,520 & 221.7 & 0.15 & 0.703 & 0.0043 & 37.2 & 1,902 & 709 & 97 & 2,708 & 4,241 & 836 & 885 & 5,962 \\
\hline 11 & 1,784 & 1,601 & 239.7 & 0.15 & 0.579 & 0.0036 & 37.5 & 1,995 & 577 & 91 & 2,663 & 3,812 & 670 & 863 & 5,345 \\
\hline 12 & 1,749 & 1,583 & 258.2 & 0.16 & 0.713 & 0.0024 & 34.5 & 2,005 & 476 & 112 & 2,593 & 3,864 & 767 & 871 & 5,502 \\
\hline 1 & 1,586 & 1,456 & 231.7 & 0.16 & 0.760 & 0.0016 & 41.4 & 2,099 & 636 & 82 & 2,817 & 4,169 & 818 & 906 & 5,893 \\
\hline 2 & 1,709 & 1,645 & 290.0 & 0.18 & 0.873 & 0.0031 & 35.3 & 2,219 & 670 & 138 & 3,027 & 3,673 & 701 & 920 & 5,294 \\
\hline 3 & 1,692 & 1,590 & 272.9 & 0.17 & 0.900 & 0.0028 & 38.1 & 2,061 & 650 & 79 & 2,792 & 3,588 & 694 & 927 & 5,209 \\
\hline 58/下小計 & 10,160 & 9,395 & 1514.2 & 0.16 & 0.755 & 0.0030 & 37.3 & 2,048 & 619 & 93 & 2,768 & 3,883 & 746 & 895 & 5,524 \\
\hline 58年度計 & 20,673 & 19,171 & 3190.5 & 0.17 & 0.832 & 0.0033 & 36.9 & 2,246 & 668 & 107 & 3,021 & 4,267 & 843 & 922 & 6,032 \\
\hline
\end{tabular}

高品位鉱画の鉱柱部の 2 次採掘に人工天盤による下向充埧採掘 法を採用し $3 \mathrm{~m} \times 2.5 \mathrm{~m}$ の加背で採掘している。1 次採掘により 生じた両側の空洞は探開坑の硑を充填した後で 2 次採掘へ移行す る。2 次採掘によつて生ずる空洞は，金網，鉄筋を敷いた上に， 坑外の充媜センターより流送される20〜25\%セメント混入のモル タル層50〜 $60 \mathrm{~cm}$ を打設し，その上に選鉱廃涬のスライムを充填す る，モルタル層が下部スライス採掘時の天盤となる。切羽内の運 搬は T L - 2 タイヤローダを使用している。

\section{4. 正撒，排水，通気}

\section{$4 \cdot 1$ 逜撒}

切羽よりスラッシャで桖き出した鉱石の積込みには太空 500 \# バケットローダを使用している。 $-20 \mathrm{~m}$ 坑, $-40 \mathrm{~m}$ 坑, $-100 \mathrm{~m}$ 坑 は人力運搬, $-80 \mathrm{~m}$ 坑, $-140 \mathrm{~m}$ 坑は $2 \mathrm{t}$ 蓄電池式機関車を使用し ている。 $0 \mathrm{~m}$ 坑以下の鉱石，磁は斜坑スキップによつて $0 \mathrm{~m}$ 坑ま で巻上げている。 $0 \mathrm{~m}$ 坑の運搬は $2 \mathrm{t}$ 蓄電池式機関車を使用して いる。坑口の破碎場で 1 次破碎し, 約 $1 \mathrm{~km}$ 離れた選鉱場へ, ダ
ンプトラックで運搬している。

$4 \cdot 2$ 排 水

$0 \mathrm{~m}$ 坑より上部の坑内水は降雨による影響を受けるが $0.3 \mathrm{~m}^{3} /$ $\min$ 程度である。 $-80 \mathrm{~m}$ 坑以下の涌水は-140m坑のポンブ座へ導 水し, $-80 \mathrm{~m}$ 坑のポンブ座で中継し， $-80 \mathrm{~m}$ 坑の坑口より排水し ている。 $-80 \mathrm{~m}$ 坑より排水される坑内水は $0.8 \mathrm{~m}^{3} / \mathrm{min}$ 程度である。 $4 \cdot 3$ 通 気

$-80 \mathrm{~m}$ 坑と $0 \mathrm{~m}$ 坑および上 $20 \mathrm{~m}$ 坑，充填立坑，大切坑坑口によ る自然通気である。探鉱坑道の一部は局部扇風機を用いている。

\section{5. 问睤点と将来の尌画}

$10^{\circ} \sim 30^{\circ}$ の 緩傾斜の 採掘の切羽内運搬はスラッシャに頼らざ るを得なく，採掘工数の半数以上がスラッシャ運転工数であり， 切羽内運搬合理化のために, 受電, 変電容量の範囲内で電動スラ ッシャの導入を計りたい。また薄い鉱床の緩傾斜採掘に，現在の ような追切発破による採掘ではおのずと採掘高さに限界があるの で,これには半長孔の応用を検討していきたい。

\section{Fujigatani Mine}

by Yoshiharu YUZAWA

Fujigatani mine is located in Kuga-gun, eastern part of Yamaguchi prefecture and its deposits are skarn type.

Production of the mine is 1,650 tons/month of tungsten ore $\left(0.95 \% \mathrm{WO}_{3}\right)$ and mining methods are 1$)$ open stoping with pillar supports and 2) underground cut and fill stoping.

This paper describes on the following points

(1) Geology and mineral deposits

(2) Mining methods

(3) Transportation, drainage and ventilation

(4) Problems on the operation and future planning. 